\title{
Bagaimana Pembelajaran Daring ditinjau dari Perspektif Merdeka Belajar pada Masa Covid 19: Berdasarkan Pendekatan Sistem
}

\author{
How the Online Learning viewed from the Freedom of Learning \\ Perspective during Covid 19: Based on a System Approach \\ Johar Permana \& Liah Siti Syarifah \\ Universitas Pendidikan Indonesia (UPI) Bandung \\ Sekolah Tinggi Agama Islam (STAI) Syamsul 'Ulum Sukabumi \\ permanajohar@upi.edu \& liahsitisyarifah.27@gmail.com
}

\begin{abstract}
Abstrak
Pembelajaran daring menjadi pilihan satuan pendidikan dalam melangsungkan proses belajar-mengajar di masa pandemi Covid 19. Terlepas dari terjadinya wabah tersebut, tipe pembelajaran yang didasarkan pada teori belajar konstruktivistik ini sangat relevan dengan kebijakan merdeka belajar. Penelitian ini bertujuan untuk menguraikan gambaran pelaksanaan pembelajaran daring pada masa Covid 19 berdasarkan pendekatan sistem. Penelitian ini menggunakan metode penelitian kepustakaan. Pengumpulan informasi serta datanya menggunakan berbagai macam bahan dan materi yang ada di perpustakaan, yaitu berupa buku, jurnal, dokumen, berita, serta sumber yang memiliki relevansi lainnya. Teknik analisis data yang digunakan dalam penelitian ini adalah content analysis dengan pendekatan dari teori sistem. Berdasarkan kajian ditemukan skema berupa alur proses pembelajaran daring dari input, proses dan output. Maka dapat disimpulkan bahwa pemetaan pembelajaran daring melalui pendekatan sistem telah memberikan gambaran umum untuk pelaksanaan pembelajaran sehingga diharapkan menjadi bekal pengetahuan untuk para pendidik dalam melaksanakan pembelajaran daring di sekolah secara efektif terutama pada masa pandemi seperti yang sedang terjadi saat ini.

Kata Kunci: Covid 19, Merdeka Belajar \& Pembelajaran Daring
\end{abstract}

\begin{abstract}
Online Learning has been the choice of the institution to carry out the teaching-learning process during the Coronavirus Disease 2019 (Covid 19). Without these conditions, the type of learning based on constructivist learning theory wass very relevant to the policy of Freedom of Learning. This research aims to describe the description of the implementation of online learning during the Covid 19 pandemic based on a systems approach. This research uses library research method. The collection of information and data uses a variety of materials in the library, namely in the form of books, journals, documents, news, and other relevant sources. The data analysis technique used
\end{abstract}


content analysis with an approach from systems theory. Based on the study, a scheme was found in the form of an online learning process flow from input,process and output. So it can be concluded that the mapping of online learning through a systems approach has provided an overview for the implementation of learning so that it is expected to be a provision of knowledge for educators in carry out online learning in schools effectively, especially during a pandemic as currently happening.

Keywords: Covid 19, Freedom of Learning \& Online Learning

\section{PENDAHULUAN}

Salah satu penerapan teknologi informasi pada dunia pendidikan adalah dalam sistem pembelajaran terutama dalam pengayaan (enrichment) pengetahuan (Supradono, 2009) sehingga penyampaian materi bahan ajar yang didukung teknologi multimedia menjadi lebih menarik dan interaktif (Moore \& Kearsley, 2005; Wagner, 1994). Pembelajaran daring (online) merupakan bagian dari pendidikan jarak jauh yang secara khusus menggabungkan teknologi elektronika dan teknologi berbasis internet (Kearsley, 2000; Turoff \& Hiltz, 1995).

Sistem pendidikan jarak jauh telah terbukti memberi kontribusi yang besar dalam menyumbang angka partisipasi kasar pendidikan tinggi (Newbury, 2013) hingga sesuai target pemerintah, hal tersebut dikarenakan dalam pendidikan jarak jauh dimungkinkan untuk melakukan pembelajaran dengan tanpa terikat jarak, kapanpun dan di manapun (Tello, 2013; Tilaar, 2009). Lebih lanjut hasil penelitian dari Joksimović dkk (2015) menegaskan bahwa pendidikan jarak jauh telah terbukti memberikan efek yang konsisten dan positif pada hasil belajar dengan tetap menjaga interaksi secara intens.

Sejak merebaknya pandemi virus Corona 19 di Indonesia, proses belajar mengajar dilakukan dari rumah (learn from home). Proses belajar dari rumah ini dilakukan melalui pembelajaran daring yang merupakan bagian dari pendidikan jarak jauh (Dewi, 2020; Widodo, 2020) dengan pemanfaatan teknologi informasi (Pakpahan \& Fitriani, 2020) sebagai media pembelajarannya. Hal ini sebagaimana menurut Blankenberger \& Williams (2020) bahwa Covid 19 telah berdampak 
pada perubahan elemen-elemen pada sistem pendidikan, yang pada gilirannya menciptakan serangkaian reaksi yang saling berhubungan dengan unsur-unsur lain sampai sistem tersebut mencapai keseimbangan baru.

Terlepas dari terjadinya wabah Corona 19, didasarkan pada karakteristik pendidikan jarak jauh, sistem pembelajaran daring sangat relevan dengan kebijakan "merdeka belajar" yang diusung Pemerintah RI. Menteri Pendidikan dan Kebudayaan, Nadiem Makarim, mengatakan bahwa kegiatan pembelajaran daring yang dilakukan selama masa pandemi ini masih akan terus dilanjutkan (Wibowo, 2020). Lebih lanjut Guru besar University of Applied Science and Arts, Hannover, Germany and Senior Experten Services (SES) Germany, Prof. Dr. Gerhad Fortwengel, menyebutkan wabah Corona 19 menjadi katalis hebat yang memacu dunia pendidikan untuk memanfaatkan teknologi informasi dalam aktivitas pembelajaran jarak jauh (Ika, 2020).

Namun begitu terdapat tantangan besar dalam pelaksanaan pembelajaran daring di Indonesia di antaranya belum terbiasanya sivitas akademika menggunakan sistem pembelajaran yang bersifat online/ daring. Belum lagi masalah penguasaan teknologi yang rendah, keterbatasan sarana dan prasarana, jaringan internet, biaya dan sebagainya (Nuryana, 2020).

Dengan pendekatan sistem, peneliti berupaya memberikan gambaran untuk pelaksanaan pembelajaran daring dengan menguraikan alur dari input, proses dan outputnya. Hal tersebut sebagaimana menurut Kerzner (2017) bahwa pendekatan sistem menekankan kesesuaian output dan input serta adanya opsi proses dalam mengolah input menjadi output.

\section{METODE PENELITIAN}

Penelitian ini menggunakan metode penelitian kepustakaan, yang mana penelitian ini dalam pengumpulan informasi serta datanya menggunakan berbagai macam bahan dan materi yang ada di perpustakaan (Galvan, 2017), yaitu berupa buku, jurnal, dokumen, majalah, kisah-kisah sejarah, berita, serta sumber yang memiliki relevansi lainnya (Dewi, 2020). Teknik analisis data yang digunakan dalam penelitian ini adalah content analysis dengan pendekatan dari teori sistem, 
melalui upaya ini diharapkan dapat menjelaskan alur proses pembelajaran daring secara sistemik.

\section{HASIL DAN PEMBAHASAN}

Kajian kepustakaan ini bertujuan untuk menyajikan kajian konseptual mengenai optimalisasi pendidikan jarak jauh berbasis online atau pembelajaran daring di masa pandemic Covid 19 yang ditinjau dari perspektif merdeka belajar. Berikut uraiannya:

\section{A. Esensi Merdeka Belajar}

Di dalam Kamus Besar Bahasa Indonesia (KBBI), kata "merdeka" diartikan sebagai berikut: (1) Bebas (dari perhambaan, penjajahan, dan sebagainya); berdiri sendiri: (2) Tidak terkena atau lepas dari tuntutan; (3) Tidak terikat, tidak bergantung kepada orang atau pihak tertentu; leluasa (Kamus Besar Bahasa Indonesia, 2019). Sedangkan "belajar" berarti proses perubahan tingkah laku, baik yang menyangkut pengetahuan, keterampilan maupun sikap berkat pengalaman dan latihan (Djamarah \& Zain, 2010). Dengan demikian, merdeka belajar bermakna memberi kesempatan belajar secara bebas kepada peserta didik dengan memperhatikan bakat yang dimiliki sehingga tumbuh dan berkembang sesuai potensi dan kemampuannya.

Merdeka belajar memiliki payung hukum yang mendasari upaya mewujudkan kualitas SDM sebagaimana tujuan kebijakan merdeka belajar (Kemendikbud RI, 2020) yaitu (a) Pembukaan UUD 1945 alinea IV: dalam rangka mencerdaskan kehidupan bangsa; (b) Pasal 31, pada ayat 3, yang menyatakan bahwa pemerintah mengusahakan dan menyelenggarakan suatu sistem pendidikan nasional, dalam rangka mencerdaskan kehidupan bangsa; (c) UU Sisdiknas Tahun 2003; menimbang bahwa sistem pendidikan nasional harus mampu menjamin pemerataan kesempatan pendidikan, peningkatan mutu serta relevansi dan efisiensi manajemen pendidikan untuk menghadapi tantangan sesuai dengan tuntutan perubahan kehidupan lokal, nasional, dan global sehingga perlu dilakukan pembaharuan pembaruan pendidikan secara terencana, terarah, dan berkesinambungan; dan (d) UU Sisdiknas tahun 2003, Pasal 3: menyebutkan bahwa pendidikan nasional berfungsi mengembangkan kemampuan dan membentuk watak serta peradaban 
bangsa yang bermartabat dalam rangka mencerdaskan kehidupan bangsa, bertujuan untuk berkembangnya potensi peserta didik agar menjadi manusia yang beriman dan bertakwa kepada Tuhan Yang Maha Esa, berakhlak mulia, sehat, berilmu, cakap, kreatif mandiri, dan menjadi warga negara yang demokratis serta bertanggung jawab; dan (e). Nawacita kelima untuk meningkatkan kualitas hidup manusia Indonesia.

Merdeka belajar bukan berarti segala sesuatu yang menyangkut pembelajaran diberi kebebasan dan kelonggaran, misalnya lalai mengerjakan tugas, tidak disiplin dan sebagainya. Akan tetapi merdeka belajar memberi kebebasan dalam "proses" untuk mencapai tujuan, dengan tetap melaksanakan semua prosedur yang ada (lpmpjatim.kemdikbud.go.id, 2020). Dalam hal ini Ki Hajar Dewantara menekankan kemerdekaan belajar pada "cara" peserta didik dalam berpikir (Rusmana, $\mathrm{tt}$ ) dengan membiarkan mereka untuk mencari dan menemukan pengetahuan dengan menggunakan pikirannya, sehingga menghasilkan "kreativitas" yang merupakan elemen penting bagi sebuah kemajuan.

Berdasarkan pengertianpengertian yang telah disajikan, konsep merdeka belajar mempunyai relevansi dengan teori belajar konstruktivistik. Teori belajar konstruktivistik sebagai teori pembelajaran yang telah diterima secara luas di lapangan (Kintsch, 2009) dan terbukti berkontribusi signifikan terhadap proses belajar mengajar (Shumba, Ndofirepi, \& Gwirayi, 2012) berfokus pada keaktifan peserta didik dalam membentuk pengetahuan (Suparno, 2001), sedangkan guru, orang tua dan pelaku pendidikan lainnnya berperan sebagai fasilitator yang menciptakan situasi kondusif untuk konstruksi pengetahuan pada diri peserta didik (Uno, 2008), kondisi tersebut bisa dilakukan melalui pendekatan individual, penggunaan metode dan media pembelajaran (Muhibbin \& Hidayatullah, 2020) yang dapat mewujudkan kegiatan belajar menyenangkan.

Dengan demikian, merdeka belajar-belajar merdeka mencirikan pembelajaran yang berkualitas, kritis, transformatif, efektif, aplikatif, variatif, progresif, aktual dan faktual. Siswa yang belajar 
berbasis kemerdekaan akan senantiasa enerjik, optimis, prospektif, kreatif dan selalu berani untuk mencoba hal baru.

\section{B. Merdeka Belajar dan Pendidikan Jarak Jauh berbasis Online di Masa Pandemi Covid 19}

Masa pandemi Covid-19 mengakibatkan terjadinya perubahan kebijakan secara mendasar dalam dunia pendidikan tanah air. Pemerintah mengambil kebijakan untuk melakukan pendidikan jarak jauh, di mana kegiatan pembelajaran tetap dilaksanakan meskipun tidak terjadi kegiatan tatap muka di sekolah. Hal ini sebagaimana menurut Prof. Aris Junaedi, Direktur Pembelajaran dan Kemahasiswaan, Direktorat Jenderal Pendidikan Tinggi, Kemendikbud bahwa pendidikan jarak jauh merupakan sistem pendidikan yang paling sesuai dengan mengacu protokol kesehatan Covid-19 yang berlaku (Harususilo, 2020).

Di sisi lain, terlepas dari terjadinya pandemi Covid 19, pendidikan jarak jauh adalah salah satu wujud dari bentuk sistem pembelajaran yang mengusung kebijakan merdeka belajar. Hal tersebut didasarkan pada berbagai pertimbangan di antaranya terkait karakteristik pendidikan jarak jauh (Sumeks.co, 2020) yang terbuka yaitu memiliki fleksibilitas tinggi dalam hal cara penyampaian materi, waktu penyelesaian program, lintas satuan, jalur dan jenis pendidikan (multi entry multi exit system), tanpa membatasi kewarganegaraan dan usia, tempat dan cara belajar, serta masa penilaian hasil belajar; mandiri yaitu proses, porsi, dan kendali belajar lebih ditentukan siswa atau mahasiswa sesuai dengan kondisi dan kecepatan belajar masingmasing; Bebas ruang dan waktu yaitu terdapat keluwesan sebagai konsekuensi pendidikan jarak jauh yang memiliki karakteristik terbuka dan belajar mandiri; dan berbasis Teknologi Informasi Dan Komunikasi (TIK) yaitu menerapkan TIK secara tepat guna untuk memfasilitasi komunikasi dan interaksi pembelajaran. Selain itu, dalam pendidikan jarak jauh yang menjadi peserta, selain siswa atau mahasiswa adalah masyarakat, yang mana masyarakat bisa mengikuti program yang ditawarkan untuk mengembangkan kapasitas pribadi sesuai dengan yang benar-benar dibutuhkan. Hal 
tersebut menjadikan merdeka belajar dan pendidikan jarak jauh sebagai bagian yang tidak terpisahkan.

Pendidikan jarak jauh merupakan pembelajaran yang tidak melakukan kontak langsung antara pengajar dan pembelajar (Munir, 2009) melainkan menggunakan "korespondensi" sebagai alat untuk berkomunikasi (Mackenzie, Christensen \& Rigby, 1968) sehingga terjadi interaksi antara pendidik dan peserta didik. Lebih lanjut Moore \& Kearsley (2005) memberikan batasan bahwa pendidikan jarak jauh adalah pembelajaran terencana yang berlangsung secara terpisah dengan pendidiknya, memerlukan desain dan teknik pembelajaran yang khusus, berkomunikasi melalui berbagai teknologi, serta menggunakan struktur organisasi dan administrasi yang khusus. Berdasarkan definisi-definisi tersebut, terdapat beberapa unsur dalam pendidikan jarak jauh yaitu penekanan pada pembelajaran, pembelajaran terjadi secara terencana dan terorganisir, pembelajaran terjadi pada ruang (dan/atau waktu) terpisah dari kegiatan pengajarannya dan pembelajar harus memiliki kemampuan belajar mandiri.

Pada dasarnya pembelajaran jarak jauh dibagi dua jenis yaitu pembelajaran luar jaringan (luring) dan pembelajaran dalam jaring (daring). Pembelajaran luring merupakan pembelajaran yang dilakukan secara offline, bisa dengan menggunakan modul belajar mandiri, televisi, radio dan sebagainya, sedangkan pembelajaran daring (online) atau yang oleh Riyana (tt) disebut sebagai pola pembelajaran bermedia digambarkan sebagai berikut:
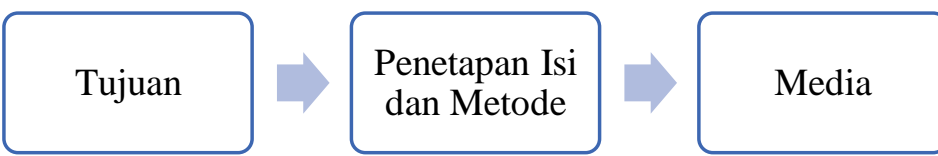

Siswa

Gambar 1 Pola Pembelajaran Bermedia (Riyana, tt)

Pembelajaran daring memiliki beberapa ciri-ciri sebagai berikut personal, structure, active dan connective (Flinders

University, 1968). (1) Personal maksudnya bahwa pengalaman belajar pada pembelajaran online diciptakan oleh siswa itu sendiri; 
(2) Structured maksudnya yaitu pembelajaran online dilakukan secara terstruktur; (3) Active maksudnya yaitu proses pembelajaran mengutamakan keaktifan peserta didik baik dalam aktif berpikir, aktif bersosialisasi maupun aktif dalam hal lainnya, keaktifan peserta didik dalam hal ini distimulus oleh pendidik melalui media pembelajaran (teknologi); (4) Connective maksudnya adanya interaksi yang dilakukan secara online antara siswa dan guru, siswa yang satu dan lainnya, menghubungkan antara tim pengajar ataupun siswa dengan staf pendidik lainnya. Dengan demikian, meskipun proses pembelajaran menitikberatkan pada penggunaan media pembelajaran, akan tetapi tetap berpusat pada manusia (peserta didik).

Berdasarkan gambar 1 tampak jelas bahwa pembelajaran daring sangat berkaitan erat dengan pemanfaatan media digital sebagai alat bantu, sehingga peserta didik maupun guru perlu memahami dan memanfaatkannya dengan baik. Dalam hal ini ada beberapa kompetensi yang perlu dimiliki guru dalam pembelajaran daring yang hal tersebut merupakan pengembangan dari 4 (empat) kompetensi utama guru yaitu penguasaan teknologi, kemampuan mengelola kelas, kemampuan komunikasi dan sosial (Sudrajat, 2020).

Mengingat peran media yang begitu sentral dalam melaksanakan pembelajaran daring, hendaknya guru gunakan media pembelajaran yang paling mungkin untuk digunakan yaitu dengan mempertimbangkan ketersediaan fasilitas, infrastruktur, lingkungan utama dan pendukung (Riyana, $t \mathrm{t}$ ). Adapun moda pemilihan media pembelajaran pada pembelajaran daring oleh seorang pendidik dideskripsikan pada gambar berikut: 


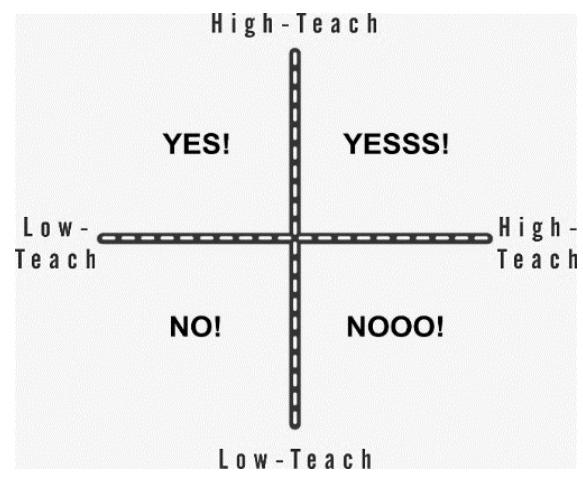

Gambar 2 Moda Pemilihan Media Pembelajaran pada Pembelajaran Daring (Chaeruman, 2018)

Skema pada gambar 2 dapat menjadi masukan dan saran bagi seorang pendidik dalam melaksanakan pembelajaran daring selama pandemi Covid 19, karena bagaimanapun pemilahan media (pembelajaran) pada pembelajaran daring sangat penting sekali, mengingat hal tersebut akan berpengaruh pada kondusifitas proses pembelajaran.

\section{Optimalisasi Pengelolaan Pendidikan Jarak Jauh (PJJ) berbasis Online}

Kajian ini fokus pada optimalisasi pengelolaan pendidikan jarak jauh yang dilakukan secara online/pembelajaran daring. Saat ini meskipun pembelajaran daring bukan lagi hanya sebagai pendidikan alternatif di Indonesia (Thaib dkk, 2016), akan tetapi pada masa pandemi Covid 19, semua institusi pendidikan seolah-olah dituntut untuk memilih jalan tersebut demi melangsungkan proses belajar mengajar. Hal tersebut bagaikan dua sisi mata uang yang menjadi peluang sekaligus tantangan dalam pelaksanaannya, pembelajaran daring harus dirancang secara matang agar dapat memfasilitasi pembelajaran peserta didik secara optimal.

Berdasarkan pendekatan sistem, pembelajaran daring dapat dideskripsikan dalam sebuah alur dari input, proses dan output sebagai berikut: 

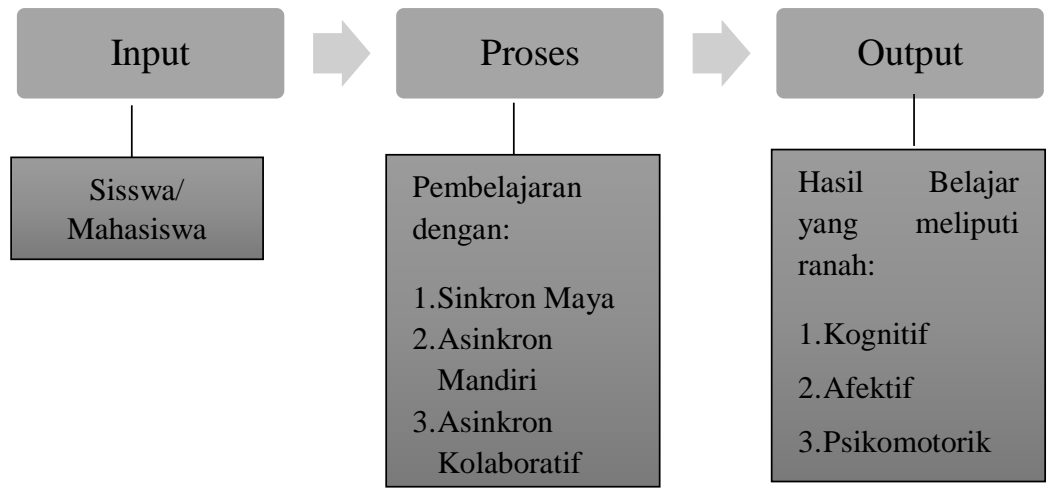

Gambar 3 Manajemen Sistem Pembelajaran Daring

Berdasasarkan gambar 5, input pembelajaran yaitu peserta didik (baik siswa maupun mahasiswa) yang dijadikan sebagai "subyek belajar" (Rusmana, tt) sehingga mereka mampu membangun kesadaran kritis untuk membentuk manusia yang merdeka. Hal tersebut sebagaimana esensi kebijakan merdeka belajar di mana peserta didik diberikan keleluasaan untuk mengembangkan bakat dan kemampuannya dalam meningkatkan kreativitas dan daya pikirnya untuk menjadi lebih baik (Mustaghfiroh, 2020).

Dalam pelaksanaan pembelajaran daring (proses), pendidik sangat perlu memperhatikan setting pembelajaran yaitu situasi dan kondisi dimana suatu peristiwa belajar bisa terjadi (Smaldino dkk, 2008) yang terdiri dari pembelajaran sinkron (synchronous learning) dan asinkron (asynchronous learning) (Naidu, 2006; Piskurich, 2006). Dari jenis-jenis setting pembelajaran tersebut, pembelajaran daring bisa dilakukan dengan sinkron maya, asinkron mandiri dan asinkron kolaboratif dengan penjelasan sebagai berikut (Chaeruman, 2018):

1. Sinkron Maya (SM) merupakan kondisi pembelajaran yang terjadi dalam situasi dimana antara peserta didik dan pendidik berada pada waktu yang sama tetapi tempat berbeda-beda satu sama lain, ini dapat dilakukan melalui teknologi sinkron seperti video conference, audio-conference atau webbased seminar (webinar).

2. Asinkron Mandiri (AM) merupakan kondisi 
pembelajaran yang terjadi dalam situasi belajar mandiri secara daring, aktivitas pembelajaran ini diantaranya adalah membaca, mendengarkan, menonton, mempraktekkan, mensimulasikan dan latihan dengan memanfaatkan obyek belajar (materi digital) tertentu yang relevan.

3. Asinkron Kolaboratif (AK) merupakan kondisi pembelajaran dalam situasi kolaboratif yang melibatkan lebih dari satu orang antara peserta didik dengan peserta didik lainnya atau orang lain sebagai narasumber. Aktivitas pembelajaran ini diantaranya difasilitasi dengan forum diskusi, mailing list, penugasan, dan lain-lain.

Untuk mengoptimalkan pembelajaran daring, hal tidak kalah penting adalah penyajian materi yang dalam hal ini seyogyanya pendidik mengelola proses pembelajaran secara profesional sehingga pembelajaran daring berlangsung dengan kondusif, misalnya dengan menggunakan model "PEDATI" (Chaeruman, 2018) yaitu sebagai berikut:

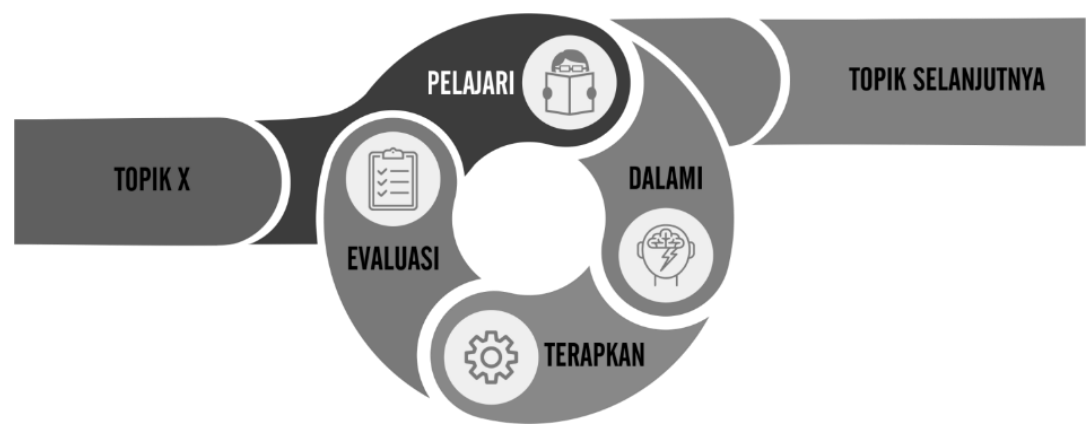

Gambar 4 Model Pembelajaran Daring (Diolah kembali dari Chaeruman, 2018)

Sebagai suatu model desain sistem pembelajaran, PEDATI menggambarkan suatu prosedur kerja yang sistematis dan logis, serta memiliki unsur-unsur (komponen) yang jelas dan berhubungan satu sama lain (Chaeruman, 2018):

1. Pelajari dimaksudakan menelaah terlebih dulu materi yang akan diberikan untuk kemudian menyediakan media digital dalam berbagai bentuk 
Merdeka Belajar pada Masa Covid 19: Berdasarkan Pendekatan Sistem E-ISSN: 2715-3649 (Johar Permana \& Liah Siti Syarifah)

dan jenis yang paling sesuai serta memungkinkan untuk digunakan dalam pembelajaran;

2. Dalami berarti fasilitasi upaya memperdalam peguasaan materi dengan meyediakan forum diskusi atau webinar atau video conference;

3. Terapkan berarti upaya menerapkan apa yang telah dipelajari dengan memberikan penugasan daring baik individu maupun kelompok;

4. Evaluasi berarti upaya mengukur penguasaan materi dengan memberikan evaluasi berupa tes obyektif yang relevan.

Terakhir output merupakan hasil belajar peserta didik (setelah proses pembelajaran) pada ranah kognitif, afektif dan psikomotorik (Mahananingtyas, 2017) secara proporsional sesuai dengan jenis dan tingkat pendidikannya.

Ranah kognitf mencakup kegiatan mental (otak) yang terdapat enam jenjang peroses berpikir, mulai dari ranah terendah sampai dengan jenjang yang paling tinggi yaitu pengetahuan/ hafalan lingatan (knowledge), pemahaman (comprehension), penerapan (application), analisis (analysis), sintesis (synthesis), dan penilaian (evaluation) (Bloom, 1956).

Ranah afektif berkaitan dengan sikap dan nilai yang menurut Anderson \& Krathwohl (2010) dirinci ke dalam lima jenjang yaitu menerima atau memperhatikan (receiving), menanggapi (responding), menilai atau menghargai (valuing), mengatur atau mengorganisasikan (organization), dan karakterisai dengan satu nilai atau kelompok nilai (characterization by a value or value complex).

Terakhir ranah psikomotor berkaitan dengan keterampilan (Simpson, 1956) yang sebenarnya merupakan kelanjutan dari hasil belajar kognitif dan hasil belajar afektif. Dengan kata lain hasil belajar psikomotorik akan didapatkan peserta didik apabila peserta didik mampu menunjukan perilaku atau perbuatan tertentu yang sesuai dengan makna yang terkandung dalam ranah kognitif dan ranah afektifnya.

Selain yang telah dipaparkan di atas, optimalisasi pembelajaran daring pada masa pandemi Covid 19 perlu didukung dengan kerjasama yang terintegrasi antara pemerintah sekolah, tenaga 
pendidik, orang tua dan peserta didiknya sendiri (Dewi, 2020; Prihatin dkk, 2019).

Peran pemerintah sangat fundamental, seyogyanya alokasi anggaran yang sudah diputuskan oleh Instruksi Presiden Nomor 4 tahun 2020 tentang refocusing kegiatan, relokasi anggaran, serta pengadaan barang dan jasa dalam rangka percepatan penanganan Covid-19 terealisasi dengan optimal, orang tua sebagai pendidik utama di rumah harus mendukung dan membimbing para putraputrinya dalam belajar, sekolah dan tenaga pendidik harus bersiaga memfasilitasi perubahan apapun menyangkut proses pembelajaran peserta didik agar pelajaran dapat benar-benar tersampaikan kepada murid, terlebih dengan pembelajaran daring pihak sekolah harus benar-benar memperhatikan etika sebagai lembaga pendidikan
(Aji, 2020). Terakhir, kerjasama dari peserta didik itu sendiri sebagai "subyek pembelajaran" yang diharapkan dapat belajar secara aktif, interaktif dan mandiri.

\section{KESIMPULAN}

Pembelajaran daring dalam perspektif merdeka belajar melibatkan proses pembelajaran yang menitikberatkan pada penggunaan media belajar sebagai alat bantu dan kreativitas di dalamnya dengan tetap berpusat pada peserta didik. Pemetaan pembelajaran daring melalui pendekatan sistem telah memberikan gambaran umum untuk pelaksanaan pembelajaran sehingga diharapkan menjadi bekal pengetahuan untuk para pendidik dalam melaksanakan pembelajaran daring di sekolah secara efektif terutama pada masa pandemi seperti yang sedang terjadi saat ini.

\section{DAFTAR PUSTAKA}

Aji, R. H. S. (2020). Dampak Covid-19 pada Pendidikan di Indonesia: Sekolah, Keterampilan, dan Proses Pembelajaran. SALAM: Jurnal Sosial \& Budaya Syar'i FSH UIN Syarif Hidayatullah Jakarta, 7 (5), 395-402. Anderson, L. W., \& Krathwohl, D. R. (2010). A Taxonomy for Learning, Teaching and Assesing: a Revision of Bloom's Taxonomy. New York: Longman Publishing. 
Blankenberger. B \& Williams. A, M. (2020). COVID and the impact on higher education: The essential role of integrity and accountability. Administrative Theory \& Praxis. 1-20.

Bloom, Benjamin S., etc. (1956). Taxonomy of Educational Objectives: The Classification of Educational Goals, Handbook I Cognitive Domain. New York : Longmans, Green and Co.

Chaeruman, U. A, (2018). PEDATI: Model Desain Sistem Pembelanjaran Blended. Diakses dari https://www.researchgate.net/publication/340377353_PEDATI_Model _Desain_Sistem_Pembelajaran_Blended Diakses pada 04 Juli 2020

Dewi, W.A .F. (2020). Dampak Covid-19 Terhadap Implementasi Pembelajaran Daring Di Sekolah Dasar. Edukatif: Jurnal Ilmu Pendidikan, 2 (1), 55-61.

Djamarah, S. B \& Zain, A. (2010). Strategi Belajar Mengajar. Jakarta: Rineka Cipta.

Flinders University. (1968). eaching online guidebook. Diakses dari https://flo.flinders.edu.au $/ \mathrm{mod} /$ book/view.php?id=854982\&chapterid=7 6465 pada 04 Juli 2020.

Galvan, Jose L. (2017). Writing Literature Reviews Sixth Edition. New York: Routledge.

Harususilo, Y. E. (2020). Webinar Nasional UT: PJJ Jadi Role Model Pendidikan Tinggi Masuk Era New Normal. Diakses dari https://edukasi.kompas.com/read/2020/06/04/133943871/webinarnasional-ut-pjj-jadi-role-model-pendidikan-tinggi-masuk-eranew?page=all pada 04 Juli 2020.

Hastuti, P. (2020). (BASIS HUKUM) Pokok-pokok Kebijakan Merdeka Belajar. Diakses dari https://www.academia.edu/41647371/BASIS_HUKUM_Pokokpokok_Kebijakan_Merdeka_Belajar pada 04 Juli 2020.

Ika. I, (2020). Membedah Tantangan Pembelajaran Daring di Tengah Pandemi Covid-19. Diakses dari https://ugm.ac.id/id/berita/19552membedah-tantangan-pembelajaran-daring-di-tengah-pandemi-covid19 pada 04 Juli 2020. 
Joksimović, S., Gašević, D., Loughin, T. M., Kovanović, V., \& Hatala, M. (2015). Learning at distance: Effects of interaction traces on academic achiev.

Kamus Besar Bahasa Indonesia (KBBI). (2019). Diakses dari https://kbbi.web.id pada 04 Juli 2020.

Kerzner, Harold. (2017). Project Management: A Systems Approach to Planning, Scheduling, and Controlling $T$ welfth $E$ dition. Canada: John Wiley \& Sons, Inc.

Kearsley, G. (2000). Online education: Learning and teaching in cyberspace.

Belmont, CA: Wadsworth/Thomson Learning.

Kemendikbud RI, (2020). Merdeka Belajar. Diakses dari https://gtk.kemdikbud.go.id/read-news/merdeka-belajar pada 04 Juli 2020.

Kintsch, W. (2009). Learning and constructivism. In S. Tobias \& T. M. Duffy

(Eds.). Constructivist theory applied to education: Success or failure?.

New York: Routledge. 223-241.

Lembaga Penjaminan Mutu Pendidikan Jawa Timur. (2020). Esensi Merdeka Belajar yang Sebenarnya. Diakses dari https://lpmpjatim.kemdikbud.go.id/site/detailpost/esensi-merdekabelajar-yang-sebenarnya pada 04 Juli 2020.

Mahananingtyas, E. (2017). Hasil Belajar Kognitif, Afektif Dan Psikomotor Melalui Penggunaan Jurnal Belajar Bagi Mahasiswa PGSD. Prosiding Seminar Nasional HDPGSDI Wilayah IV Tahun 2017. 192-200.

Moore, M. \& Kearsley, G. (2005). Distance Education: A Systems View (Second Edition). USA: Thomson Wadsworth.

Muhibbin \& Hidayatullah, M. A. (2020). Implemntasi Teori Belajar Konstruktivisme Vygotsky Pada Mata Pelajaran Pai Di SMA Sains Qur`An Yogyakata. Belajea: Jurnal Pendidikan Islam, 5 (1), 113-130.

Munir. (2009). Pembelajaran Jarak Jauh Berbasis Teknologi Informasi dan Komunikasi. Bandung: Alfabeta, 2009.

Mustaghfiroh, S. (2020). Konsep Merdeka Belajar Perspektif Aliran Progresivisme John Dewey. Jurnal Studi Guru dan Pembelajaran, 3 (1), 141-147.

Naidu, S. (2006). E-learning. A Guidebooks of Principles, Procedures and Practices, 2nd Revised Edition. Cemka. 
Newbury, R. (2013). Are design elements in blended learning courses factors of student completion rate?. International Journal of Technology in Teaching \& Learning, 9 (2), 139-158.

Nuryana. A, N, (2020). Dampak Pandemi Covid 19 terhadap Dunia Pendidikan. Diakses dari https://kabar-priangan.com/dampak-pandemicovid-19-terhadap-dunia-pendidikan/ pada 04 Juli 2020.

Pakpahan, R. \& Fitriani, Y. (2020). Analisa Pemanfaatan Teknologi Informasi

Dalam Pembelajaran Jarak Jauh Di Tengah Pandemi Virus Corona Covid-19”, Journal of Information System, Applied, Management, Accounting and Research, 4 (2), 30-36.

Piskurich, G. M. (2006). Rapid Instructional Design: Learning ID Fast and Right (Second Edition). San Fransisco, CA: Pfeiffer, John Wiley and Sons, Inc.

Prihatin, Eka., Aprilia, Imas Diana., Permana, Johar \& Syarifah, Liah Siti. (2019). Sinergitas Sekolah dengan Pemerintah, Masyarakat dan DuniaDunia Usaha/ Industri: Sebuah Langkah Optimalisasi Pengelolaan Pendidikan Life Skill pada Siswa Disabilitas. Jurnal Penelitian Pendidikan, 19 (3), 334-343.

Riyana, C. (tt). Konsep Pembelajaran Online. Diakses dari http://www.pustaka.ut.ac.id/lib/wp-content/uploads/pdfmk/TPEN4401M1.pdf.

Rusmana, F. a. I. (2020). Memerdekakan Siswa Melalui Pendidikan: Relevansi Konsepsi Pemikiran Pendidikan Ki Hadjar Dewantara. Diakses dari http://repository.unj.ac.id/724/4/Memerdekakan\%20Siswa\%20Melalui \%20Pendidikan\%20\%28Jurnal\%29.pdf pada 4 Juli 2020.

Smaldino, Sharon E., Lowther, Deborah L., Russel, James D. (2008). Instructional Technology and Media for Learning (Ninth Edition). NJ: Pearson Education Inc.

Shumba, A., Ndofirepi, A. P., \& Gwirayi, PA. (). Critique of Constructivist Theory in Science Teaching and Learning. Journal of Social Sciences, 31 (1), 11-18.

Sudrajat, Jajat. (2020). Kompetensi Guru di Masa Pandemi Covid-19. Jurnal Riset Ekonomi dan Bisnis, 13 (1), 300-310. 
Sumec.co. (2020). Merdeka Belajar dan Belajar Jarak Jauh. Diakses dari https://sumeks.co/merdeka-belajar-dan-belajar-jarak-jauh/ pada 04 Juli 2020.

Suparno, A. S. (2001). Membangun Kompetensi Belajar. Direktorat Jendral Pendidikan Tinggi Departemen Pendidikan Nasional.

Supradono. B. (2011). Kerangka Kerja OCTAVE untuk Manajemen Risiko Keamanan Informasi Sistem E-Learning (Studi Kasus: Sistem ELearning Universitas Muhammadiyah Semarang). Teknik Elektro Universitas Muhammadiyah Semarang.

Thaib, D., Wahyudin, D., Rahmawati, Y \& Riyana, C. (2016). Studi Analisis Kebutuhan Terhadap Pengembangan Model Blended Learning Pada Sistem Pendidikan Jarak Jauh Untuk Meningkatkan Kompetensi Lulusan. EduHumaniora: Jurnal Pendidikan Dasar, 8 (2), 107-125.

Tello. S. F. (2007). An analysis of student persistence in online education", International Journal of Information and Communication Technology Education, 3 (3), 47-62.

Tilaar, H.A.R. (2009). Kekuasaan dan Pendidikan: Kajian Menejemen Pendidikan Nasional dalam Pusaran Kekuasaan. Jakarta: Rinika Cipta. Turoff, M., \& Hiltz, R. S. (1995). Designing and evaluating a virtual classroom. Journal of Information Techn.

Uno, H. B. (2008). Teori Motivasi dan Pengukurannya. Jakarta: Bumi Aksara. Wagner, E. D. (1994). In support of a functional definition of interaction. The American Journal of Distance Education, 8 (2), 6-28.

Wibowo. C. (2020). Merdeka Belajar Nadiem Makarim Tak Akan Tercapai Kalau Tak Ada Perbaikan Pembelajaran Jarak Jauh. Diakses dari https://prfmnews.pikiran-rakyat.com/nasional/pr-13584732/merdekabelajar-nadiem-makarim-tak-akan-tercapai-kalau-tak-ada-perbaikanpembelajaran-jarak-jauh pada 04 Juli 2020.

Widodo, H. (2020). Manajemen Pembelajaan Daring. Diakses dari https://radarjogja.jawapos.com/2020/04/15/manajemen-pembelajarandaring/ pada 04 Juli 2020. 